\title{
Effect of tea catechins with caffeine on energy expenditure in middle-aged men and women: a randomized, double-blind, placebo-controlled, crossover trial
}

\author{
Shun Katada ${ }^{1} \cdot$ Aya Yanagimoto $^{1} \cdot$ Yuji Matsui $^{1} \cdot$ Masanobu Hibi $^{1} \cdot$ Noriko Osaki $^{1} \cdot$ Shigeru Kobayashi $^{2}$. \\ Yoshihisa Katsuragi ${ }^{3}$
}

Received: 23 August 2018 / Accepted: 25 April 2019 / Published online: 6 May 2019

(c) The Author(s) 2019

\begin{abstract}
Purpose It has been reported that tea catechins increase energy metabolism, but their effect on resting metabolic rate (RMR) remains under debate. This study aimed to examine the effect of repeated intake of tea catechins on energy metabolism in the resting state in middle-aged men and women.

Methods A total of 30 middle-aged men and women [13 women; age (mean \pm SD) $52 \pm 4$ years; BMI $21.9 \pm 2.2 \mathrm{~kg} / \mathrm{m}^{2}$ ] were recruited. A randomized, double-blind, crossover study was conducted using a tea catechin-enriched beverage $(611 \mathrm{mg}$ catechins, $88 \mathrm{mg}$ caffeine) and a placebo beverage ( $0 \mathrm{mg}$ catechins, $81 \mathrm{mg}$ caffeine) as test beverages. After 2 weeks of continuous test beverage intake, fasting RMR and energy expenditure (EE) after the ingestion of test beverage were measured. Measurements of forehead temperature (proxy for core temperature) and skin temperature were also obtained simultaneously. Results Among participants who underwent measurements, 26 (10 women; mean age $52 \pm 4$ years; mean BMI $22.1 \pm 2.1 \mathrm{~kg}$ / $\mathrm{m}^{2}$ ) were analyzed. The EE increased significantly after ingestion of the tea catechin beverage compared with the placebo beverage (placebo treatment: $5502 \pm 757 \mathrm{~kJ} / \mathrm{day}$; catechin treatment: $5598 \pm 800 \mathrm{~kJ} / \mathrm{day} ; P=0.041$ ). No between-treatment differences in fasting RMR or the respiratory quotient were detected. In addition, the forehead and skin temperature did not differ significantly between the placebo and catechin treatments.

Conclusion This study revealed that continuous intake of tea catechins with caffeine for 2 weeks significantly increased EE after ingestion of the tea catechin but not fasting RMR in middle-aged men and women.

Clinical Trial Registry number and website This trial was registered at www.umin.ac.jp/ctr/ as UMIN000025810 and UMIN000025811.
\end{abstract}

Keywords Body temperature $\cdot$ Energy expenditure $\cdot$ Middle-aged men and women $\cdot$ Resting metabolic rate $\cdot$ Tea catechins

Electronic supplementary material The online version of this article (https://doi.org/10.1007/s00394-019-01976-9) contains supplementary material, which is available to authorized users.

Shun Katada and Aya Yanagimoto contributed equally to this work.

Shun Katada

katada.shun@kao.com

1 Biological Science Research Laboratories, Kao Corporation, 2-1-3 Bunka, Sumida, Tokyo 131-8501, Japan

2 Department of Surgery, Tokyo Rinkai Hospital, 1-4-2 Rinkai-cho, Edogawa, Tokyo 134-0086, Japan

3 Health Care Food Research Laboratories, Kao Corporation, 2-1-3 Bunka, Sumida, Tokyo 131-8501, Japan

$\begin{array}{ll}\text { Abbreviations } \\ \text { DBP } & \text { Diastolic blood pressure } \\ \text { DEXA } & \text { Dual-energy X-ray absorptiometry } \\ \text { EE } & \text { Energy expenditure } \\ \text { EGCg } & \text { Epigallocatechin gallate } \\ \text { FFM } & \text { Fat-free mass } \\ \text { FM } & \text { Fat mass } \\ \text { FSH } & \text { Follicle-stimulating hormone } \\ \text { HbA1c } & \text { Glycated hemoglobin } \\ \text { iAUC } & \text { Incremental area under the curve } \\ \text { LH } & \text { Luteinizing hormone } \\ \text { RMR } & \text { Resting metabolic rate } \\ \text { RQ } & \text { Respiratory quotient } \\ \text { SBP } & \text { Systolic blood pressure } \\ \text { T3 } & \text { Triiodothyronine } \\ \text { T4 } & \text { Thyroxine }\end{array}$


TEE Total energy expenditure

TSH Thyroid-stimulating hormone

$\dot{V} \mathrm{O}_{2} \quad$ Oxygen consumption

$\dot{V} \mathrm{CO}_{2} \quad$ Carbon dioxide production

\section{Introduction}

Obesity and overweight are major global health problems and critical risk factors for diabetes and cardiovascular disease [1]. Weight gain is attributed to excessive energy intake, as represented by overeating or decreased energy expenditure (EE), or both [2,3]. An imbalance between energy intake and EE results in weight fluctuation, and a slightly positive energy balance per day (around $200 \mathrm{~kJ} /$ day) is thought to cause long-term weight gain [4].

Enhancement of EE by plant-derived ingredients, in addition to dietary restrictions and exercise, has attracted attention as a method for adjusting the energy balance [5]. Tea catechins (polyphenols contained in green tea) are one of these plant-derived ingredients with the potential to improve energy balance [6]. A synergistic effect of caffeine, which is also rich in green tea, was also reported for the thermogenic effect of catechin [7]. The intake of tea catechins with caffeine increases total energy expenditure (TEE) and fat utilization [8-10], and studies examining the effects of an acute single ingestion of tea catechins with caffeine report significant increases in EE compared with a placebo [9, 11], but other studies report inconsistent effects of continuous tea catechin with caffeine intake on fasting resting metabolic rate (RMR) [12, 13]. Moreover, although fasting RMR is known to decrease with age [14, 15], previous studies mostly targeted young healthy subjects to examine the effects of tea catechin with caffeine [8-11] and there are few studies describing the effects of tea catechin intake on fasting RMR and $\mathrm{EE}$ after ingestion in middle-aged individuals.

In this study, we examined the effects of continuous intake over 2 weeks of a tea catechin with caffeine on fasting RMR and EE after ingestion of the tea catechin in middleaged men and women. We also measured the forehead and skin temperature simultaneously to confirm the effect of tea catechins with caffeine on body temperature.

\section{Methods}

\section{Participants}

Thirty healthy volunteers (17 men and 13 women; mean age $52 \pm 4$ years; mean BMI $21.9 \pm 2.2 \mathrm{~kg} / \mathrm{m}^{2}$ ) participated in this crossover trial. The inclusion criterion was $45-65$ years of age. Exclusion criteria were as follows: treatment for severe disease; history or signs of a heart or cerebrovascular disease; taking therapeutic medicine for diabetes, hyperlipidemia or hypertension; smoker; heavy drinker; anemia; food allergies; and hypersensitivity to the test beverages. This trial was performed in accordance with the Declaration of Helsinki, and the trial plan was reviewed and approved by the local ethics committee (Kao Corporation, Tokyo, Japan). All subjects provided their informed, written consent to participate in the study. Recruitment of participants was conducted in January 2017. The treatment period was from February to April 2017.

\section{Test beverages}

The test beverages were prepared by the Kao Corporation. The beverage referred to as the catechin beverage contained 611-mg catechins and $88-\mathrm{mg}$ caffeine in $350 \mathrm{~mL}$, and the caffeinated-placebo beverage contained $0-\mathrm{mg}$ catechins and 81 -mg caffeine in $350 \mathrm{~mL}$ (Table 1). The catechin beverage contained catechins comprising catechin (6\%), epicatechin (5\%), gallocatechin (22\%), epigallocatechin (19\%), catechin gallate (4\%), epicatechin gallate (6\%), gallocatechin gallate (18\%), and epigallocatechin gallate (EGCg, 19\%). The catechin beverage used in this study is commercially available in Japan, with the production standard of total tea catechins set to $174-190 \mathrm{mg} / 100 \mathrm{~mL}$ to guarantee a total tea catechin content of $540 \mathrm{mg} / 350 \mathrm{~mL}$.

\section{Experimental design}

This study was a two-phase, randomized, double-blind, placebo-controlled, crossover trial with a 2-week washout period between measurement periods (Supplemental Fig. 1). Subjects were randomized by stratified randomization to balance for BMI. The primary endpoint was energy metabolism after a 2-week intervention. After baseline measurements, subjects consumed one test beverage per day for 2 weeks while maintaining their usual lifestyle. Measurements on

Table 1 Composition of the test beverages

\begin{tabular}{lcc}
\hline & Placebo beverage & $\begin{array}{c}\text { Catechin } \\
\text { beverage }\end{array}$ \\
\hline Catechin (mg) & 0 & 34 \\
Epicatechin (mg) & 0 & 32 \\
Gallocatechin (mg) & 0 & 134 \\
Epigallocatechin (mg) & 0 & 118 \\
Catechin gallate (mg) & 0 & 25 \\
Epicatechin gallate (mg) & 0 & 39 \\
Gallocatechin gallate (mg) & 0 & 111 \\
Epigallocatechin gallate (mg) & 0 & 118 \\
Total catechins (mg) & 0 & 611 \\
Caffeine (mg) & 81 & 88 \\
\hline
\end{tabular}


day 14 of phase 1 were obtained between 08:15 and 12:00. After a washout period of 2 weeks, in phase 2, subjects consumed the other test beverage per day for 2 weeks, again while maintaining their usual lifestyle. On day 14 of phase 2 , measurements were obtained according to the same timecourse used in phase 1 . At each measurement period, energy metabolism and body temperature were measured before and after the test beverage ingestion and blood samples were obtained. During the trial, subjects were instructed to avoid intake of drinks/foods that contain a high amount of catechins, caffeine, and red pepper, and to maintain their usual exercise and dietary habits. Subjects also ate prescribed meals starting with breakfast up to dinner the day before each measurement period $(10113 \mathrm{~kJ} /$ day; protein, $13 \mathrm{E} \%$; fat, $25 \mathrm{E} \%$, carbohydrates, $62 \mathrm{E} \%$ for men and $8163 \mathrm{~kJ} / \mathrm{day}$; protein, $13 \mathrm{E} \%$; fat, $26 \mathrm{E} \%$, carbohydrates, $62 \mathrm{E} \%$ for women, respectively) and were prohibited from performing strenuous exercise and drinking alcohol. The day before the measurement, subjects ate their prescribed meal by 20:00 and fasted thereafter.

\section{Anthropometrics and body composition}

Body weight was measured using an automatic scale (TF780, Tanita, Tokyo, Japan) and body composition was measured using whole-body dual-energy X-ray absorptiometry (DEXA, Hologic Inc., QRD 4500 W, Waltham, MA). Measurements of the fat-free mass (FFM), fat mass (FM), and fat ratio (\%) were obtained using Hologic Systems Software according to the Hologic QRD 4500 User's Guide.

\section{Indirect calorimetry}

On measurement days, subjects were rested in a supine position on a bed, awake, in a fasting condition and in a room with a fixed environment (room temperature, $25^{\circ} \mathrm{C}$; humidity, 50\%) for at least $30 \mathrm{~min}$ (8:30-9:00) before measurement of fasting RMR [16]. Using a hood-type respiratory gas analyzer (ARCO2000, Arco System, Inc., Chiba, Japan) [17], we assessed oxygen consumption $\left(\dot{V} \mathrm{O}_{2}\right)$ and carbon dioxide production $\left(\dot{V} \mathrm{CO}_{2}\right)$, and measured fasting RMR between 9:00 and 9:30 before the test beverage ingestion (Fig. 1). At 09:50, subjects consumed the test beverage within $5 \mathrm{~min}$.
Following this, EE after ingestion of the test beverage was measured three times at intervals of 15-30 min, between 10:00 and 11:30 as described above and the values from 10:00 to 11:30 were averaged to determine the EE after ingestion of the test beverage. $\dot{V} \mathrm{O}_{2}$ and $\dot{V} \mathrm{CO}_{2}$ were used to determine the $\mathrm{EE}[18]$ and respiratory quotient (RQ). The technical validity of the indirect calorimeter was repeatedly assessed by an alcohol combustion test throughout each trial on a weekly basis, repeated nine times. The coefficient of variation calculated from repeated measurement of the combustion rate was $1.2 \%$.

\section{Measurements of body temperature and activity}

In parallel with measurement of the EE, the forehead temperature (proxy for core temperature) was monitored by applying a temperature sensor (SpotOn ${ }^{\mathrm{TM}}$ Temperature Monitoring System, 3M, St Paul, USA) [19] to the forehead and using a data logger (LT-200, Gram, Saitama, Japan). The skin temperature was monitored using skin temperature sensors (LT-2N-12, Gram, Saitama, Japan) on the left subclavicular region and the left foot sole. A motion logger (Actigraph, MicroMini, AMI, NY, USA) was used to detect activity during the measurement of fasting RMR and EE after ingestion of the test beverage [20].

\section{Blood analysis}

Blood was drawn at 9:30 am under fasting conditions. Fasting blood glucose and glycated hemoglobin (HbAlc) were measured using enzymatic methods. Fasting serum insulin, free triiodothyronine (T3), free thyroxine (T4), thyroid-stimulating hormone (TSH), progesterone, luteinizing hormone (LH), follicle-stimulating hormone (FSH) and estradiol were measured using a chemiluminescence immunoassay. Fasting serum total cholesterol, LDL cholesterol, HDL cholesterol, and triglycerides were measured using enzymatic methods. Fasting plasma noradrenaline was measured by HPLC and cortisol was measured by a chemiluminescence immunoassay. Measurements of parameters were performed by LSI Medience Corporation (Tokyo, Japan).

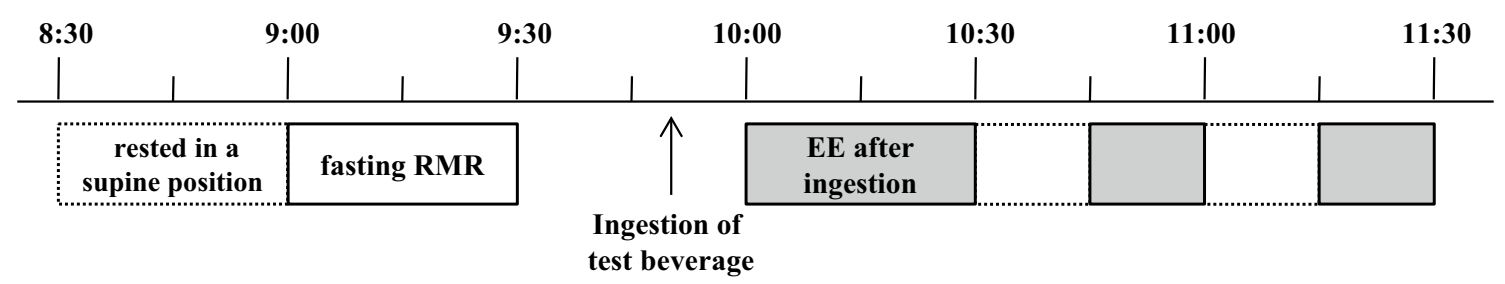

Fig. 1 Diagrammatic representation of the study design 


\section{Statistical analysis}

Unless otherwise specified, all values are presented as mean \pm SD. All cross-over data for the two treatments were compared using the paired $\mathrm{t}$ test (two-sided, $\alpha=0.05$ ). The relationship between FFM and fasting RMR was assessed using the Pearson correlation. Sample size was calculated based on a power analysis using preliminary data. A study group of 32 subjects was required for a power of $90 \%$ at a $5 \%$ significance level. All statistical analyses were performed with IBM SPSS Statistics for Windows, ver.19.0 (SPSS Inc., IL, USA).

\section{Results}

Thirty healthy individuals participated in this study, and all participants completed the study. To accurately measure the fasting RMR and EE after ingestion of the test beverage, a motion logger Actigraph was used, and outliers in the dataset were detected on the basis of the interquartile range. Three subjects with an activity level greater than $1.5 \times$ the interquartile range above the third quartile during the fasting RMR and EE after ingestion of the test beverage measurement were excluded from the analysis; one subject who took medicine during the measurement periods was also excluded and a per-protocol analysis was performed in twenty-six subjects (mean age $52 \pm 4$ years; mean BMI: $22.1 \pm 2.1 \mathrm{~kg} / \mathrm{m}^{2}$ ). The characteristics of the subjects are shown in Table 2. The rate of intake of the test beverage during the intervention period was $100 \%$ in both treatments.

\section{Energy metabolism}

A significant positive correlation was observed between the fasting RMR and the FFM of subjects in both the placebo treatment $(r=0.891, P<0.001)$ and the catechin treatment $(r=0.856, P<0.001)$. Table 3 shows fasting RMR, EE after ingestion of the test beverage and RQ following the 2-week intervention. Before ingestion of the test beverage, the fasting RMR did not differ significantly between the catechin treatment and the placebo treatment. On the other hand, the EE after ingestion of the test beverage was significantly higher in the catechin treatment than in the placebo treatment [placebo: $5502 \pm 757 \mathrm{~kJ} /$ day; catechin: $5598 \pm 800 \mathrm{~kJ} / \mathrm{day} ; P=0.041$; mean difference: 96 kJ/day (95\% CI 4-188), Table 3 and Fig. 2]. A repeatedmeasures ANOVA revealed a significant treatment effect $(P=0.008)$, while there was no significant interaction between time and treatment $(P=0.584)$. Although incremental area under the curve (iAUC) at 45-90 min tend to be significantly higher in the catechin treatment (placebo:
Table 2 Subject characteristics at baseline

\begin{tabular}{lc}
\hline Age, y & $52 \pm 4$ \\
Sex, M/F, $n$ & $16 / 10$ \\
Height $(\mathrm{cm})$ & $166.4 \pm 8.2$ \\
Body weight $(\mathrm{kg})$ & $61.6 \pm 9.6$ \\
BMI $\left(\mathrm{kg} / \mathrm{m}^{2}\right)$ & $22.1 \pm 2.1$ \\
FFM $(\mathrm{kg})$ & $47.2 \pm 8.4$ \\
FM $(\mathrm{kg})$ & $14.4 \pm 4.3$ \\
Fat ratio $(\%)$ & $23.4 \pm 6.4$ \\
SBP $(\mathrm{mmHg})$ & $123 \pm 19$ \\
DBP $(\mathrm{mmHg})$ & $76 \pm 15$ \\
Glucose $(\mathrm{mg} / \mathrm{dL})$ & $86 \pm 7$ \\
HbA1c $(\%)$ & $5.4 \pm 0.2$ \\
Insulin $(\mu \mathrm{U} / \mathrm{mL})$ & $2.8 \pm 1.4$ \\
Total cholesterol $(\mathrm{mg} / \mathrm{dL})$ & $197 \pm 23$ \\
LDL cholesterol $(\mathrm{mg} / \mathrm{dL})$ & $114 \pm 25$ \\
HDL cholesterol $(\mathrm{mg} / \mathrm{dL})$ & $60 \pm 12$ \\
Triglycerides $(\mathrm{mg} / \mathrm{dL})$ & $92 \pm 41$ \\
Free T3 $(\mathrm{pg} / \mathrm{mL})$ & $3.1 \pm 0.3$ \\
Free T4 $(\mathrm{ng} / \mathrm{dL})$ & $1.2 \pm 0.2$ \\
TSH $(\mu \mathrm{IU} / \mathrm{mL})$ & $1.140 \pm 0.560$ \\
Noradrenaline $(\mathrm{ng} / \mathrm{mL})$ & $0.33 \pm 0.11$ \\
Cortisol $(\mu \mathrm{g} / \mathrm{dL})$ & $7.8 \pm 2.5$ \\
\hline
\end{tabular}

Data are expressed as mean $\pm \mathrm{SD}, n=26$

$D B P$ diastolic blood pressure, $F F M$ fat-free mass, $F M$ fat mass, $H b A 1 c$ glycated hemoglobin, $T 3$ triiodothyronine, $T 4$ thyroxine, $T S H$ thyroid-stimulating hormone, SBP systolic blood pressure

$8 \pm 6 \mathrm{~kJ} / 45 \mathrm{~min}$; catechin: $11 \pm 8 \mathrm{~kJ} / 45 \mathrm{~min} ; P=0.099$ ), no significant differences were observed at $0-90 \mathrm{~min}$ (placebo: $15 \pm 10 \mathrm{~kJ} / 90 \mathrm{~min}$; catechin: $18 \pm 13 \mathrm{~kJ} / 90 \mathrm{~min}$; $P=0.181$, Supplemental Fig. 2). No significant differences were observed in RQ (Table 3).

\section{Body temperature}

Table 4 shows changes in body temperature during energy metabolism measurements. Before ingestion of the test beverage, the forehead temperature and skin temperature did not differ significantly between the catechin treatment and the placebo treatment. Similarly, after ingestion of the test beverage, the forehead temperature and skin temperature did not differ significantly between the catechin treatment and the placebo treatment. Regression analyses showed no association between changes in RMR and changes in forehead temperature [placebo: $y=0.0001 x+0.117, R^{2}=0.029$, catechin: $y=0.0001 x+0.132, R^{2}=0.063, x$; changes in RMR $(\mathrm{kJ} /$ day), $y$; changes in forehead temperature $\left({ }^{\circ} \mathrm{C}\right), R^{2}$; coefficient of determination]. 
Table 3 Resting metabolic rate (RMR), energy expenditure (EE) after ingestion of test beverages and respiratory quotient (RQ) after the 2-week intervention

\begin{tabular}{llll}
\hline & Placebo treatment & Catechin treatment & $P$ value \\
\hline Fasting RMR (kJ/day) & $5269 \pm 781$ & $5291 \pm 780$ & 0.681 \\
EE after ingestion (kJ/day) & $5502 \pm 757$ & $5598 \pm 800$ & $0.041^{\mathrm{a}}$ \\
Changes in EE (kJ/day) & $233 \pm 209$ & $307 \pm 259$ & 0.186 \\
Fasting RQ & $0.868 \pm 0.041$ & $0.874 \pm 0.035$ & 0.398 \\
RQ after ingestion & $0.854 \pm 0.026$ & $0.863 \pm 0.035$ & 0.104 \\
Changes in RQ & $-0.015 \pm 0.024$ & $-0.011 \pm 0.030$ & 0.525 \\
\hline
\end{tabular}

Data are expressed as mean $\pm \mathrm{SD}, n=26$

${ }^{\text {a }}$ Paired $t$ test $P<0.05$

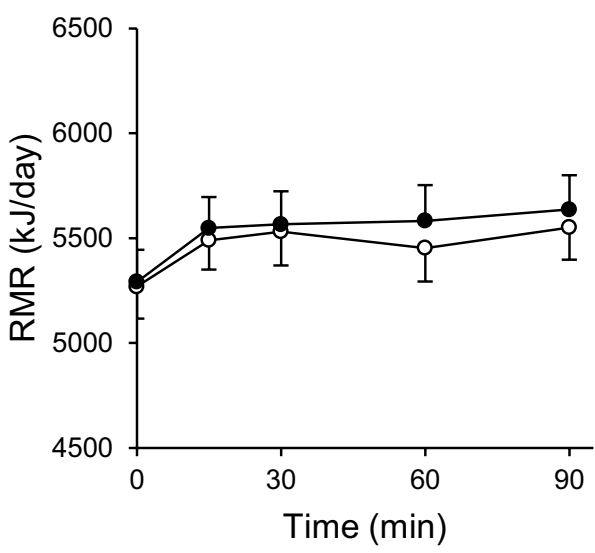

Fig. 2 Time profile of fasting RMR and EE after ingestion following the 2-week intervention (placebo treatment: open circles; catechin treatment: closed circles). Data are expressed as mean \pm SEM, $n=26$, repeated measures ANOVA revealed significant treatment effect (treatment effect, $P=0.008$; time effect, $P<0.001$; treatment $\mathrm{x}$ time, $P=0.584)$

Table 4 Forehead and skin temperature after the 2-week intervention

Placebo treatment Catechin treatment $P$ value

\begin{tabular}{lccc}
\hline \multicolumn{3}{c}{ Forehead (proxy for core temperature) } & \\
Fasting $\left({ }^{\circ} \mathrm{C}\right)$ & $36.66 \pm 0.32$ & $36.59 \pm 0.29$ & 0.114 \\
After ingestion & $36.80 \pm 0.35$ & $36.77 \pm 0.34$ & 0.384 \\
$\quad\left({ }^{\circ} \mathrm{C}\right)$ & & & \\
Changes in temp & $0.15 \pm 0.16$ & $0.17 \pm 0.14$ & 0.331 \\
$\quad\left({ }^{\circ} \mathrm{C}\right)$ & & \\
Left subclavicular skin & & \\
Fasting $\left({ }^{\circ} \mathrm{C}\right)$ & $34.61 \pm 0.56$ & $34.63 \pm 0.52$ & 0.713 \\
$\begin{array}{l}\text { After ingestion } \\
\left({ }^{\circ} \mathrm{C}\right)\end{array}$ & $34.70 \pm 0.56$ & $34.70 \pm 0.50$ & 0.996 \\
Changes in temp & $0.09 \pm 0.31$ & $0.06 \pm 0.32$ & 0.693 \\
$\quad\left({ }^{\circ} \mathrm{C}\right)$ & & & \\
Left foot sole skin & & & \\
Fasting $\left({ }^{\circ} \mathrm{C}\right)$ & $29.83 \pm 2.27$ & $29.94 \pm 2.06$ & 0.807 \\
After ingestion & $28.29 \pm 1.50$ & $28.23 \pm 1.26$ & 0.857 \\
$\quad\left({ }^{\circ} \mathrm{C}\right)$ & & & \\
Changes in temp & $-1.54 \pm 1.17$ & $-1.70 \pm 1.20$ & 0.388 \\
$\left({ }^{\circ} \mathrm{C}\right)$ & & & \\
\hline
\end{tabular}

Data are expressed as mean $\pm \mathrm{SD}, n=26$

\section{Blood parameters and anthropometrics}

Fasting blood parameters after the 2-week intervention are shown in Table 5. Glucose, insulin, total cholesterol, LDL cholesterol, HDL cholesterol, triglycerides, free T3, free T4, $\mathrm{TSH}$, noradrenaline, and cortisol levels did not differ significantly between treatments. Although we could not confirm the menstruation cycles in female subjects, the progesterone, LH, FSH, and estradiol levels in the female subjects did not differ significantly between the treatments. Body weight and body fat were measured using an automatic scale after the 2-week intervention, and there are no differences between catechin and placebo treatment (body weight; placebo treatment: $61.4 \pm 9.6 \mathrm{~kg}$; catechin treatment: $61.5 \pm 9.6 \mathrm{~kg}$; $P=0.463$, body fat; placebo treatment: $24.9 \pm 5.6 \%$; catechin treatment: $24.7 \pm 5.6 \% ; P=0.289$ ).

\section{Discussion}

The findings of the present study demonstrated that repeated intake of a tea catechin with caffeine for 2 weeks significantly increased $\mathrm{EE}$ after ingestion by $96 \mathrm{~kJ} /$ day (6 kJ/90 min) compared with the placebo beverage in middle-aged men and women. Our results suggest that repeated intake of tea catechins with caffeine over a 2-week increased the EE after ingestion of the catechin in the resting state by $1.7 \%$ in participants whose mean age was 52 years, which may have significant implications for obesity and weight gain associated with aging.

Previous studies examining the effects of tea catechin with caffeine intake on energy metabolism using a metabolic chamber reported increases in $24 \mathrm{~h}$ TEE after the beverage ingestion $[8,10]$. On the other hand, conflicting findings are reported on the effects of tea catechins or EGCg with caffeine; in some studies, increases in the resting EE were observed in the tea catechin treatment compared with the control treatment $[9,11]$, whereas other studies detected no such differences $[21,22]$. Although the present study revealed that continuous intake of a tea catechin-enriched 
Table 5 Blood parameters after the 2-week intervention

\begin{tabular}{llll}
\hline & Placebo treatment & Catechin treatment & $P$ value \\
\hline Glucose $(\mathrm{mg} / \mathrm{dL})$ & $86 \pm 7$ & $85 \pm 7$ & 0.256 \\
Insulin $(\mu \mathrm{U} / \mathrm{mL})$ & $3.3 \pm 1.5$ & $3.5 \pm 1.7$ & 0.552 \\
Total cholesterol $(\mathrm{mg} / \mathrm{dL})$ & $191 \pm 23$ & $191 \pm 24$ & 0.975 \\
LDL cholesterol $(\mathrm{mg} / \mathrm{dL})$ & $110 \pm 23$ & $110 \pm 25$ & 1.000 \\
HDL cholesterol $(\mathrm{mg} / \mathrm{dL})$ & $59 \pm 13$ & $59 \pm 13$ & 1.000 \\
Triglycerides $(\mathrm{mg} / \mathrm{dL})$ & $93 \pm 39$ & $96 \pm 44$ & 0.632 \\
Free T3 $(\mathrm{pg} / \mathrm{mL})$ & $3.2 \pm 0.3$ & $3.2 \pm 0.3$ & 0.658 \\
Free T4 $(\mathrm{ng} / \mathrm{dL})$ & $1.1 \pm 0.2$ & $1.1 \pm 0.1$ & 1.000 \\
TSH $(\mu \mathrm{IU} / \mathrm{mL})$ & $1.239 \pm 0.730$ & $1.249 \pm 0.745$ & 0.899 \\
Noradrenaline $(\mathrm{ng} / \mathrm{mL})$ & $0.32 \pm 0.13$ & $0.30 \pm 0.09$ & 0.206 \\
Cortisol $(\mu \mathrm{g} / \mathrm{dL})$ & $7.2 \pm 1.9$ & $7.1 \pm 1.9$ & 0.839 \\
Progesterone $(\mathrm{ng} / \mathrm{mL})$ & $4.9 \pm 7.4$ & $4.4 \pm 6.8$ & 0.819 \\
LH $(\mathrm{mIU} / \mathrm{mL})$ & $15.69 \pm 16.36$ & $16.47 \pm 16.93$ & 0.503 \\
FSH $(\mathrm{mIU} / \mathrm{mL})$ & $38.54 \pm 38.94$ & $40.89 \pm 41.03$ & 0.337 \\
Estradiol $(\mathrm{pg} / \mathrm{mL})$ & $61 \pm 68$ & $77 \pm 94$ & 0.387 \\
\hline
\end{tabular}

Data are expressed as mean $\pm \mathrm{SD}, n=26$ [progesterone, $\mathrm{LH}, \mathrm{FSH}$ and estradiol were measured in female subjects $(n=10)]$

FSH follicle-stimulating hormone, $L H$ luteinizing hormone, T3 triiodothyronine, T4 thyroxine, TSH thyroid-stimulating hormone beverage for 2 weeks significantly increased the EE after ingestion, further studies are needed to examine individual differences, changes in body composition due to continuous intake over a prolonged period of time, and the effects of dietary interventions.

In the present study, a $1.7 \%$ increase in the EE after ingestion was observed in the catechin treatment compared with the placebo treatment, which was statistically significant and consistent with previously reported thermogenic ingredientsinduced increases in EE (2-4\%) [5]. Similar to tea catechins, it has been reported that capsinoids also increase the EE and enhance the activation of brown adipose tissue [23, 24]. Galgani et al. observed an approximately $3 \%$ increase in the EE after pill ingestion in a parallel-group study using dihydrocapsiate [25]. Although these reported changes in the EE are relatively small, the resulting energy balance would be negative if there was no change in the dietary intake or exercise habits, thus having implications for long-term weight management.

Roughly, two-thirds of the fasting RMR is estimated to produce heat for homeothermy [26]. In the present study, we measured the non-invasive forehead (proxy for core) temperature as well as the skin temperature at the same time as the fasting RMR and EE after ingestion measurements were obtained; however, we detected no clear difference between the catechin and placebo treatments. In a previous study targeting Asian women with sensitivity to cold temperatures, fermented green tea suppressed decreases in limb temperature in mildly cold conditions $\left(18-20^{\circ} \mathrm{C}\right)$ [27]. Gosselin et al. examined the effects of EGCg with caffeine on thermogenesis under cold stimulation $\left(15^{\circ} \mathrm{C}\right)$, and reported that EGCg with caffeine increased nonshivering thermogenesis [28]. In the present study, energy metabolism measurements were obtained under $25^{\circ} \mathrm{C}$ room temperature, which might make it difficult to detect a relatively small change in body temperature by tea catechin ingestion.

The test beverages using in this study contained approximately the same amount of caffeine (catechin beverage: 88-mg caffeine; placebo beverage: $81-\mathrm{mg}$ caffeine), and it is likely that the $\mathrm{EE}$ after ingestion increase observed in this study is largely attributable to catechin itself. However, it is proposed that catechins and caffeine have a synergistic interaction on thermogenesis in brown adipose tissue [7, 29]. Thus, we cannot exclude a synergistic effect of tea catechins and caffeine to increase the $\mathrm{EE}$ after ingestion.

The mechanism of a tea catechin with caffeine-induced EE increase likely also involves the activation of AMP-activated protein kinase. It has been reported that tea catechins increase EE in mice through AMP-activated protein kinase $\alpha$ activation and enhancement of lipid metabolism [30]. In the present study, participants were in the fasting state for over $12 \mathrm{~h}$ at the time of test beverage intake, and because they were not given a meal or supplied with lipids and carbohydrates along with the test beverage, a decrease in the RQ might not have occurred. Moreover, tea catechins with caffeine reportedly activate brown adipose tissue in young people [9, 31]. Although it is possible that the tea catechin with caffeine-induced EE increase involves the activation of brown adipose tissue, further studies are needed to evaluate the effects of tea catechins with caffeine on brown adipose 
tissue in middle-aged individuals. Furthermore, the relatively short study period of 2 weeks might not have been sufficient to observe the effects of tea catechins with caffeine on body weight and body composition. To confirm these effects, a longer intervention period might be necessary.

In conclusion, the present study revealed that continuous intake of tea catechins with caffeine for 2 weeks significantly increased EE after ingestion but not fasting RMR in middleaged men and women. Although a decline in energy metabolism due to aging may be inevitable, tea catechins with caffeine could help to maintain long-term energy metabolism, and hence, the management of body weight.

Acknowledgements This study was funded by Kao Corporation.

Funding Supported by Kao Corporation, Tokyo, Japan

\section{Compliance with ethical standards}

Conflict of interest This study was funded by Kao Corporation. S. Katada, A. Yanagimoto, Y. Matsui, M. Hibi, N. Osaki, and Y. Katsuragi are employees of the Kao Corporation. S. Kobayashi has no personal or financial conflicts of interest. The sponsor had no control over the interpretation, writing, or publication of this work.

Open Access This article is distributed under the terms of the Creative Commons Attribution 4.0 International License (http://creativeco mmons.org/licenses/by/4.0/), which permits unrestricted use, distribution, and reproduction in any medium, provided you give appropriate credit to the original author(s) and the source, provide a link to the Creative Commons license, and indicate if changes were made.

\section{References}

1. Haslam DW, James WPT (2005) Obesity. Lancet 366:1197-1209

2. Stubbs RJ, Hughes DA, Johnstone AM, Horgan GW, King N, Blundell JE (2004) A decrease in physical activity affects appetite, energy, and nutrient balance in lean men feeding ad libitum. Am J Clin Nutr 79:62-69

3. Schoeller DA (2009) The energy balance equation: looking back and looking forward are two very different views. Nutr Rev 67:249-254. https://doi.org/10.1111/j.1753-4887.2009.00197.x

4. Hill JO (2009) Can a small-changes approach help address the obesity epidemic? A report of the joint task force of the American Society for Nutrition, Institute of Food Technologists, and International Food Information Council. Am J Clin Nutr 89:477-484. https://doi.org/10.3945/ajcn.2008.26566

5. Hursel R, Westerterp-Plantenga MS (2010) Thermogenic ingredients and body weight regulation. Int J Obes 34:659-669. https ://doi.org/10.1038/ijo.2009.299

6. Hursel R, Viechtbauer W, Dulloo AG, Tremblay A, Tappy L, Rumpler W, Westerterp-Plantenga MS (2011) The effects of catechin rich teas and caffeine on energy expenditure and fat oxidation: a meta-analysis. Obes Rev 12:e573-581. https://doi. org/10.1111/j.1467-789X.2011.00862.x

7. Dulloo AG (2011) The search for compounds that stimulate thermogenesis in obesity management: from pharmaceuticals to functional food ingredients. Obes Rev 12:866-883. https://doi. org/10.1111/j.1467-789X.2011.00909.x
8. Dulloo AG, Duret C, Rohrer D, Girardier L, Mensi N, Fathi M, Chantre P, Vandermander J (1999) Efficacy of a green tea extract rich in catechin polyphenols and caffeine in increasing 24-h energy expenditure and fat oxidation in humans. Am J Clin Nutr 70:1040-1045

9. Yoneshiro T, Matsushita M, Hibi M, Tone H, Takeshita M, Yasunaga K, Katsuragi Y, Kameya T, Sugie H, Saito M (2017) Tea catechin and caffeine activate brown adipose tissue and increase cold-induced thermogenic capacity in humans. Am J Clin Nutr 105:873-881. https://doi.org/10.3945/ajcn.116.14497 2

10. Rudelle S, Ferruzzi MG, Cristiani I, Moulin J, Macé K, Acheson KJ, Tappy L (2007) Effect of a thermogenic beverage on 24-hour energy metabolism in humans. Obesity 15:349-355

11. Hursel R, Janssens PL, Bouwman FG, Mariman EC, Westerterp-Plantenga MS (2014) The role of catechol-O-methyl transferase Val (108/158) Met polymorphism (rs4680) in the effect of green tea on resting energy expenditure and fat oxidation: a pilot study. PLoS One 9:e106220

12. Auvichayapat P, Prapochanung M, Tunkamnerdthai O, B-o Sripanidkulchai, Auvichayapat N, Thinkhamrop B, Kunhasura S, Wongpratoom S, Sinawat S, Hongprapas P (2008) Effectiveness of green tea on weight reduction in obese Thais: a randomized, controlled trial. Physiol Behav 93:486-491. https://doi. org/10.1016/j.physbeh.2007.10.009

13. Hursel R, Westerterp-Plantenga MS (2009) Green tea catechin plus caffeine supplementation to a high-protein diet has no additional effect on body weight maintenance after weight loss. Am J Clin Nutr 89:822-830. https://doi.org/10.3945/ ajen.2008.27043

14. Geisler C, Braun W, Pourhassan M, Schweitzer L, Glüer C-C, Bosy-Westphal A, Müller M (2016) Age-dependent changes in resting energy expenditure (REE): insights from detailed body composition analysis in normal and overweight healthy caucasians. Nutrients 8:322. https://doi.org/10.3390/nu8060322

15. Elia M, Ritz P, Stubbs RJ (2000) Total energy expenditure in the elderly. Eur J Clin Nutr 54(3):S92-103

16. Compher C, Frankenfield D, Keim N, Roth-Yousey L (2006) Best practice methods to apply to measurement of resting metabolic rate in adults: a systematic review. J Am Diet Assoc 106:881-903. https://doi.org/10.1016/j.jada.2006.02.009

17. Hirano M, Yamada Y, Hibi M, Katashima M, Higaki Y, Kiyonaga A, Tanaka H (2014) Simultaneous multiple-subject analysis of respiratory gas exchange in humans. J Phys Fitness Sport Med 3:269-279. https://doi.org/10.7600/jpfsm.3.269

18. Weir JdV (1949) New methods for calculating metabolic rate with special reference to protein metabolism. J Physiol 109:1-9

19. Eshraghi Y, Nasr V, Parra-Sanchez I, Van Duren A, Botham M, Santoscoy T, Sessler DI (2014) An evaluation of a zero-heat-flux cutaneous thermometer in cardiac surgical patients. Anesth Analg 119:543-549. https://doi.org/10.1213/ane.0000000000000319

20. Cole RJ, Kripke DF, Gruen W, Mullaney DJ, Gillin JC (1992) Automatic sleep/wake identification from wrist activity. Sleep $15: 461-469$

21. Thielecke F, Rahn G, Böhnke J, Adams F, Birkenfeld AL, Jordan J, Boschmann M (2010) Epigallocatechin-3-gallate and postprandial fat oxidation in overweight/obese male volunteers: a pilot study. Eur J Clin Nutr 64:704-713. https://doi.org/10.1038/ ejen.2010.47

22. Gahreman D, Wang R, Boutcher Y, Boutcher S (2015) Green tea, intermittent sprinting exercise, and fat oxidation. Nutrients 7:5646-5663. https://doi.org/10.3390/nu7075245

23. Yoneshiro T, Aita S, Kawai Y, Iwanaga T, Saito M (2012) Nonpungent capsaicin analogs (capsinoids) increase energy expenditure through the activation of brown adipose tissue in humans. Am J Clin Nutr 95:845-850 
24. Nirengi S, Homma T, Inoue N, Sato H, Yoneshiro T, Matsushita M, Kameya T, Sugie H, Tsuzaki K, Saito M (2016) Assessment of human brown adipose tissue density during daily ingestion of thermogenic capsinoids using near-infrared time-resolved spectroscopy. J Biomed Opt 21:091305-091305

25. Galgani JE, Ravussin E (2010) Effect of dihydrocapsiate on resting metabolic rate in humans. Am J Clin Nutr 92:1089-1093. https://doi.org/10.3945/ajen.2010.30036

26. Landsberg L (2012) Core temperature: a forgotten variable in energy expenditure and obesity? Obes Rev 13(Suppl 2):97-104. https://doi.org/10.1111/j.1467-789X.2012.01040.x

27. Lee E, Bj Lee, Ha J, Hj Shin, Jo Chung (2016) Efficacy of fermented green tea on peripheral skin temperature: a randomized and placebo-controlled clinical study. J Cosmet Dermatol $15: 226-230$

28. Gosselin C, Haman F (2012) Effects of green tea extracts on nonshivering thermogenesis during mild cold exposure in young men.
Br J Nutr 110:282-288. https://doi.org/10.1017/s00071145120050 89

29. Dulloo A, Seydoux J, Girardier L, Chantre P, Vandermander J (2000) Green tea and thermogenesis: interactions between catechin-polyphenols, caffeine and sympathetic activity. Int J Obes $24: 252$

30. Murase T, Misawa K, Haramizu S, Hase T (2009) Catechininduced activation of the LKB1/AMP-activated protein kinase pathway. Biochem Pharmacol 78:78-84. https://doi.org/10.1016/j. bcp.2009.03.021

31. Nirengi S, Amagasa S, Homma T, Yoneshiro T, Matsumiya S, Kurosawa Y, Sakane N, Ebi K, Saito M, Hamaoka T (2016) Daily ingestion of catechin-rich beverage increases brown adipose tissue density and decreases extramyocellular lipids in healthy young women. Springerplus 5:1363 